\title{
Theory versus practice of energy and comfort in 4 low energy houses in
} Belgium

\author{
Griet Verbeeck $^{1, *}$, Werner Carmans ${ }^{1}$, Veerle Martens ${ }^{1}$ \\ ${ }^{1}$ PHL University College, Diepenbeek, Belgium \\ *Tel: +32 11249207, Fax: +32 11249201, E-mail:gverbeeck@mail.phl.be
}

\begin{abstract}
Climate change made governments introduce energy performance regulations like the Energy Performance of Buildings Directive (EPBD) and these regulations will be tightened in the future. However, the real performance of current low energy dwellings does not always match the theoretical expected performance and therefore lessons can be learned from the real performance of these houses for future low energy houses.

For four low energy houses, energy consumption and indoor climate have been analyzed through calculations, monitoring and occupant surveys. All houses appeared to be more energy saving in theory and practice than the current Flemish building standard, but with large differences between the houses and with still a large potential for improvement, especially the heating systems. Also the measured $\mathrm{CO}_{2}$ concentrations in winter strongly differed between the houses and the occupants' perception of indoor air quality did not always match the measured quality. The weakest point according to the surveys was summer comfort, especially in the sleeping rooms, but this was not always confirmed by measurements and calculations. This shows that common comfort theories are not adapted to dwellings and that summer comfort should be evaluated in detail during design. These lessons should be taken into account when designing and evaluating future low energy houses.
\end{abstract}

Keywords: Post-occupancy evaluation, Energy, Thermal comfort, Indoor air quality, Occupant behavior

\section{Introduction}

The challenges of climate change and the exhaustibility of natural resources made governments all over the world introduce energy performance regulations in order to avoid the construction of energy devouring buildings. These regulations will be tightened in the future, as is already the case with the recent recast of the EU EPBD. Architects and building occupants however do not wait for the tightening to build dwellings that performa better than the legal standard. In Flanders, Belgium, in 2006 at the introduction of the Flemish EPBD version (called EPB), only $2.5 \%$ of all new dwellings performed at least $40 \%$ better than the legal standard (according to the theoretical calculated energy performance level) whereas in 2009 already $11 \%$ of all new dwellings performed at least $40 \%$ better than the legal standard [1]. Weak point is that these are theoretical performances and that there often is a discrepancy between theory and practice [2,3]. In order to improve the real performance of future low energy houses, the knowledge of real energy and comfort performance of present low energy houses should be increased. In this research the post-occupancy performance of four low energy houses has been analyzed for the aspects of energy consumption and indoor climate (thermal comfort and relative humidity $(\mathrm{RH})$ in winter and summer, and indoor air quality (IAQ) in winter). Underlying to the analysis were following questions: (1) are these houses as energy saving in practice as calculated in theory? and (2) is the indoor climate satisfactory in these houses, both in winter and summer? In this paper, first, the methodology is presented with a description of the four houses and the calculation method for energy consumption and summer comfort. Also the monitoring campaign is described as well as the survey and the evaluation criteria for energy and indoor climate. Then, the main results of this evaluation are presented and discussed. Finally conclusions are formulated on lessons to learn from this post-occupancy evaluation for the design of future low energy houses. 


\section{Methodology}

\subsection{Description of the low energy houses}

The dwellings are all located in the province of Limburg, Flanders, near the border with The Netherlands and Germany. Three dwellings are newly constructed and one old dwelling is thoroughly renovated. House 1, 2 and 3 are designed (or renovated) by the same architect, chosen by the occupants for her expertise with energy saving dwellings, whereas for the architect of house 4, it was his first low energy house and also the occupants were not familiar with low energy concepts. The main characteristics of the dwellings are given in Table 1.

Table 1. Characteristics of the dwellings

\begin{tabular}{|c|c|c|c|c|}
\hline & House 1 & House 2 & House 3 & House 4 \\
\hline $\begin{array}{c}\text { Construction } \\
\text { year }\end{array}$ & 2005 & 2004 & $\begin{array}{l}\text { 1830, renovated in } \\
2002\end{array}$ & 2007 \\
\hline Typology & Detached & Detached & Detached & Semi-detached \\
\hline \# occupants & 6 & 5 & 5 & 3 \\
\hline Volume & $687 \mathrm{~m}^{3}$ & $952 \mathrm{~m}^{3}$ & $770 \mathrm{~m}^{3}$ & $629 \mathrm{~m}^{3}$ \\
\hline Floor area & $294 \mathrm{~m}^{2}$ & $333 \mathrm{~m}^{2}$ & $278 \mathrm{~m}^{2}$ & $252 \mathrm{~m}^{2}$ \\
\hline Heat loss area & $549 \mathrm{~m}^{2}$ & $549 \mathrm{~m}^{2}$ & $530 \mathrm{~m}^{2}$ & $419 \mathrm{~m}^{2}$ \\
\hline $\mathrm{U}_{\text {mean }}$ & $0.30 \mathrm{~W} / \mathrm{m}^{2} \mathrm{~K}$ & $0.28 \mathrm{~W} / \mathrm{m}^{2} \mathrm{~K}$ & $0.50 \mathrm{~W} / \mathrm{m}^{2} \mathrm{~K}$ & $0.30 \mathrm{~W} / \mathrm{m}^{2} \mathrm{~K}$ \\
\hline $\begin{array}{l}\text { Glass to floor } \\
\text { ratio }\end{array}$ & $24 \%$ & $18 \%$ & $28 \%$ & $14 \%$ \\
\hline $\begin{array}{l}\text { Heat } \\
\text { production } \\
\text { system }\end{array}$ & $\begin{array}{l}\text { Soapstone wood } \\
\text { stove + backup } \\
\text { boiler on gas }\end{array}$ & $\begin{array}{c}\text { Condensing boiler } \\
\text { on gas + wood } \\
\text { stove }\end{array}$ & $\begin{array}{c}\text { Soapstone wood } \\
\text { stove + electrical } \\
\text { heater in bathroom }\end{array}$ & $\begin{array}{c}\text { Condensing } \\
\text { boiler on gas }\end{array}$ \\
\hline $\begin{array}{l}\text { Domestic hot } \\
\text { water system }\end{array}$ & $\begin{array}{c}\text { Storage tank } \\
\text { connected to } \\
\text { wood stove }+ \\
\text { boiler backup }\end{array}$ & $\begin{array}{l}\text { Storage tank } \\
\text { connected to } \\
\text { boiler on gas }\end{array}$ & $\begin{array}{c}\text { Storage tank } \\
\text { connected to wood } \\
\text { stove + electrical } \\
\text { backup }\end{array}$ & $\begin{array}{l}\text { Storage tank } \\
\text { connected to } \\
\text { boiler on gas }\end{array}$ \\
\hline $\begin{array}{l}\text { Heat emission } \\
\text { system }\end{array}$ & $\begin{array}{l}\text { Floor and wall } \\
\text { heating }\end{array}$ & $\begin{array}{l}\text { Floor heating and } \\
\text { radiators }\end{array}$ & Stove & Floor heating \\
\hline $\begin{array}{l}\text { Ventilation } \\
\text { system }\end{array}$ & $\begin{array}{l}\text { Balanced } \\
\text { ventilation with } \\
\text { ground pipe and } \\
\text { heat recovery, } \\
\text { summer bypass }\end{array}$ & $\begin{array}{c}\text { Balanced } \\
\text { ventilation with } \\
\text { ground pipe and } \\
\text { heat recovery, no } \\
\text { summer bypass }\end{array}$ & $\begin{array}{l}\text { Mechanical supply, } \\
\text { connected to } \\
\text { ground pipe, } \\
\text { natural exhaust }\end{array}$ & $\begin{array}{c}\text { Balanced } \\
\text { ventilation with } \\
\text { ground pipe (not } \\
\text { yet installed) }\end{array}$ \\
\hline $\begin{array}{l}\text { Renewable } \\
\text { solar energy }\end{array}$ & $\begin{array}{l}10 \mathrm{~m}^{2} \text { thermal } \\
\text { collectors }\end{array}$ & $\begin{array}{l}4.7 \mathrm{~m}^{2} \text { thermal } \\
\text { collectors }\end{array}$ & $\begin{array}{l}4.14 \mathrm{~m}^{2} \text { thermal } \\
\text { collectors }\end{array}$ & $\begin{array}{l}4.8 \mathrm{~m}^{2} \text { thermal } \\
\text { collectors }\end{array}$ \\
\hline
\end{tabular}

\subsection{Calculation of energy consumption and summer comfort}

Both the calculation method for energy consumption and the assessment method for summer comfort, applied in this research, form part of the Flemish version of the EPBD (further called EPB). The main principles of these calculation procedures are described below. 


\subsubsection{Calculated energy consumption}

The end energy and primary energy consumption for heating and domestic hot water are calculated with the calculation procedure for the EPB. The procedure is mainly based on the EN ISO 13790(2004). It is a steady state monthly based one-zone model, taking into account the insulation quality of the building envelope, useful internal and solar heat gains, performance of ventilation system and heating system and presence of renewable energy systems. Despite the simplifications, the energy consumption calculated with a monthly based steady state one-zone model is very comparable with the energy consumption calculated with a dynamic multi-zone model [5]. The average indoor temperature is $18^{\circ} \mathrm{C}$ for heating. The outdoor climate is the Test Reference Year of Brussels, Belgium. In the calculation procedure, the volume of domestic hot water used depends on the building volume and the energy consumption for domestic hot water depends on the performance of the heat production system, presence of a storage tank and a solar collector and length of pipes. Also the auxiliary electricity consumption for pumps and fans is calculated. The EPB considers a primary energy conversion factor for electricity of 2.5 .

\subsubsection{Calculated risk for summery overheating}

In the EPB for dwellings, also the risk for summery overheating is assessed, through the overheating indicator. The indicator is calculated based on the yearly surplus heat gains compared to the set point temperature of $18^{\circ} \mathrm{C}$. The surplus gains depend on the overall monthly heat gains (internal and solar), the thermal capacity of the building and the proportion of heat losses to heat gains. For the overheating indicator a threshold value of $8000 \mathrm{Kh}$ and a maximum value of $17500 \mathrm{Kh}$ is set. Below the threshold value, no risk for summery overheating is expected, above the maximum value the summer comfort is totally unacceptable and the designer is obliged to take measures to improve the summer comfort. Between threshold and maximum value, a real risk for summery overheating is assumed, linearly depending on the distance to the threshold value. This means that it is assumed that in practice, there is a real risk that the occupant will install an active cooling system after the house is built, thus increasing his energy consumption significantly. Weakness of this steady state one-zone model is that summer comfort is evaluated at the level of the overall building, whereas overheating typically is a local and dynamic problem that not necessarily occurs in all rooms of a dwelling. But since this method, as part of the EPB method, is used in Flanders to enhance the awareness of architects for summery overheating, it also has been used within this research to roughly assess the summer comfort.

\subsection{Monitoring of energy consumption and indoor climate}

In the dwellings, indoor climate and energy consumption are monitored from March 2009 until February 2010. The indoor temperature and RH are measured every 15 minutes with an ONSET HOBO H8 logger in the living room and in a north oriented and a south oriented sleeping room. During the winter (November 2009 till January 2010) also the $\mathrm{CO}_{2}$ concentration in the living room is measured every 5 minutes with a Telaire 7001, coupled with a HOBO H8 logger. With a maximum distance of $30 \mathrm{~km}$ between the dwellings, the outdoor temperature and RH are only measured at one location. The energy consumption of natural gas, electricity and wood have been noted by the occupants on at least a weekly basis.

\subsection{Survey of the building occupants}

Apart from calculations and monitoring, also the occupants are surveyed. Their behavior as well as their perception of the indoor climate is analyzed through a survey on the winter and summer situation. Questions are asked on their presence in the house during daytime, on their 
habits of opening windows, setting off the heating system during absence and taking measures against summery overheating during absence. Also occupants have to evaluate their perception of thermal comfort, draft and IAQ through a scale of $[-3,-2,-1,0,1,2,3]$ for thermal comfort, a scale of $[0,1,2,3]$ for draft and $[-3,-2,-1,0]$ for IAQ, for winter and summer for the rooms that are monitored. Also questions are asked on the adaptation of the heating system to fluctuating indoor temperatures (eg. due to change in solar irradiation) and whether any room is uncomfortably warm or cold at a certain time of the day.

\subsection{Evaluation criteria for energy consumption and indoor climate}

To assess the real performance of the low energy houses and to compare the theoretical performance with the real performance, the following evaluation criteria have been used.

For energy consumption, the monitored consumption of all energy carriers (gas, electricity, wood) in each house is normalized into an end energy consumption in $\mathrm{kWh} /$ year per $\mathrm{m}^{2}$ floor area and a primary energy consumption in $\mathrm{kWh} /\left(\mathrm{m}^{2}\right.$.year). Gas and wood consumption are first normalized for a standard year by means of the degree day method (1800 degree days during monitoring and 2087 degree days in a standard year in Brussels). This is compared with the theoretical energy consumption according to the EPB. Since electricity for household appliances and lighting is included in the monitored electricity consumption, but not in the EPB, both the primary energy consumption with and without electricity is given as a result. However, by excluding the electricity consumption, also the electricity for pumps, fans and eventually electrical backup for domestic hot water is excluded. As the results will show, this makes it difficult to mutually compare the houses.

For thermal comfort, the mean indoor temperature and standard deviation are calculated from the monitored data for winter and summer for the different rooms. Also the percentage of time, the temperature in the different rooms is below, in or above the comfort zone is calculated. For the winter situation a comfort zone of $20^{\circ} \mathrm{C}-24^{\circ} \mathrm{C}$ is set for the living room and $18^{\circ} \mathrm{C}-22^{\circ} \mathrm{C}$ for the sleeping rooms; for the summer a comfort zone of $23^{\circ} \mathrm{C}-26^{\circ} \mathrm{C}$ is set for all rooms. This is based on ISO 7730:1994 [4] for a maximum PPD (Predicted percentage of dissatisfied) of $20 \%$. Weak point is that this comfort theory is developed for office buildings. In fact, none of the current comfort theories (Fanger, adaptive model, weighted temperature exceedings,...) is adapted to assess thermal comfort in dwellings and certainly not in sleeping rooms. The measured results for thermal comfort are compared with the perceived thermal comfort by the occupants and with the calculated overheating indicator.

The IAQ is assessed by means of the $\mathrm{RH}$ and the $\mathrm{CO}_{2}$ concentration. The comfort zone for $\mathrm{RH}$ is $30-70 \%$. For $\mathrm{CO}_{2}$ concentration, four IAQ-levels are considered: IDA1 $(<400 \mathrm{ppm}$ above outdoor level), IDA2 (400-600ppm above outdoor level), IDA3 (600-1000ppm above outdoor level) and IDA4 (> 1000ppm above outdoor level). An outdoor level of 400ppm is assumed. For a good IAQ normally at least an IDA2 level has to be aimed for. The results are compared with the perceived IAQ by the occupants.

\section{Results}

\subsection{Energy consumption}

Table 2 presents the monitored energy consumption for the four houses, with a distinction between yearly consumption of gas and wood for space heating and domestic hot water (row 1 and 2) and yearly electricity consumption for household, lighting, fans and pumps (row 3). In case of house 3, this includes also backup heating for domestic hot water. 
Table 2. Monitored yearly energy consumption in all four houses, normalized for outdoor climate

\begin{tabular}{lcccc}
\hline & House 1 & House 2 & House 3 & House 4 \\
\hline Gas [kWh/yr] & 3.201 & 5.577 & - & 9.301 \\
Wood [kWh/yr] & 16.036 & 1.053 & 8.992 & - \\
Electricity [kWh/yr] & 3.881 & 5.768 & 10.188 & 2.970 \\
\hline Total end energy [kWh/yr] & 23.118 & 12.398 & 19.180 & 12.271 \\
\hline
\end{tabular}

Based on these data, the total end energy consumption per year and per $\mathrm{m}^{2}$ floor area is calculated, as well as the total primary energy consumption, including and excluding the electricity consumption. Also the energy consumption according to the EPB is calculated, representing the energy consumption for space heating, domestic hot water and auxiliary electrical energy for pumps and fans. Also here the total end energy consumption per year and per $\mathrm{m}^{2}$ floor area is calculated, as well as the total primary energy consumption, including and excluding the electricity consumption (here for fans and pumps). These results are shown in figure 1, with the light grey bars representing the monitoring results and the dark grey bars the theoretical consumption. The black bar represents the maximum allowable energy consumption for these houses (in $\mathrm{kWh} / \mathrm{m}^{2}$ ) according to the current Flemish regulation for new dwellings. Although house 3 is renovated and not obliged to meet the regulation for new dwellings, here it is treated as if it were a new dwelling. Results are discussed in section 4.

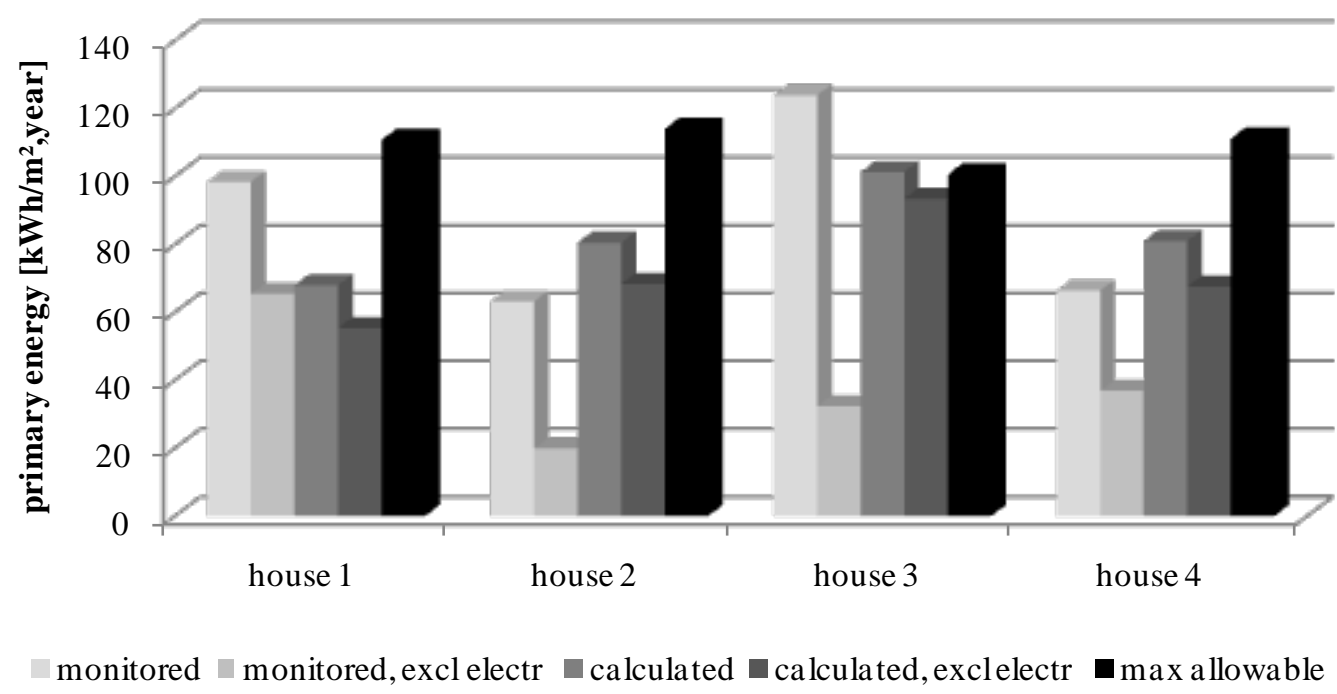

Fig. 1. Comparison of monitored and calculated primary energy consumption (in $\mathrm{kWh} / \mathrm{m}^{2}$,year) for all four houses, with distinction between energy consumption with and without electricity consumption.

\subsection{Indoor temperature and thermal comfort}

Table 3 gives for each house the mean temperature \pm standard deviation in the three monitored rooms during the months November 2009 till January 2010 and during the months June till August 2009. For each room also the percentage of time that the indoor temperature lies in the comfort zone is given. For the remaining time in winter, the temperature is nearly always below the comfort zone. For the summer also the percentage of time the temperature is above the comfort zone is presented, as it is an indication for summery overheating.

Table 4 presents the overheating indicator for all houses, calculated as described in section 2.2.2. Based on the threshold and maximum allowable value also the risk that an active cooling installation will be installed afterwards is calculated and presented in table 4 . 
Table 3. Indoor temperature in winter and summer in living room, sleeping room north and south in all houses

\begin{tabular}{|c|c|c|c|c|}
\hline November 2009 - January 2010 & House 1 & House 2 & House 3 & House 4 \\
\hline \multicolumn{5}{|c|}{ Living room } \\
\hline Mean temp \pm stand.deviation $\left[{ }^{\circ} \mathrm{C}\right]$ & $22,2 \pm 0,7$ & $21,4 \pm 0,6$ & $20,2 \pm 2,1$ & $20,7 \pm 0,5$ \\
\hline$\%$ time in comfort zone & $100 \%$ & $98 \%$ & $72 \%$ & $91 \%$ \\
\hline \multicolumn{5}{|c|}{ Sleeping room north } \\
\hline Mean temp \pm stand.deviation $\left[{ }^{\circ} \mathrm{C}\right]$ & $18,0 \pm 1,3$ & $14,8 \pm 2,0$ & $18,6 \pm 1,7$ & $19,3 \pm 0,6$ \\
\hline$\%$ time in comfort zone & $41 \%$ & $13 \%$ & $68 \%$ & $99 \%$ \\
\hline \multicolumn{5}{|c|}{ Sleeping room south } \\
\hline Mean temp \pm stand.deviation $\left[{ }^{\circ} \mathrm{C}\right]$ & $17,3 \pm 1,3$ & $15,7 \pm 1,7$ & $17,7 \pm 1,6$ & $20,3 \pm 0,5$ \\
\hline$\%$ time in comfort zone & $25 \%$ & $8 \%$ & $31 \%$ & $100 \%$ \\
\hline June 2009 - August 2009 & House 1 & House 2 & House 3 & House 4 \\
\hline \multicolumn{5}{|c|}{ Living room } \\
\hline Mean temp \pm stand.deviation $\left[{ }^{\circ} \mathrm{C}\right]$ & $24,9 \pm 1,0$ & $24,0 \pm 1,0$ & $24,3 \pm 1,8$ & $24,1 \pm 1,1$ \\
\hline$\%$ time in comfort zone & $88 \%$ & $78 \%$ & $80 \%$ & $81 \%$ \\
\hline$\%$ time above comfort zone & $11 \%$ & $1 \%$ & $5 \%$ & $6 \%$ \\
\hline \multicolumn{5}{|c|}{ Sleeping room north } \\
\hline Mean temp \pm stand.deviation $\left[{ }^{\circ} \mathrm{C}\right]$ & $24,6 \pm 1,2$ & $23,9 \pm 1,2$ & $24,4 \pm 1,1$ & $24,5 \pm 1,0$ \\
\hline$\%$ time in comfort zone & $81 \%$ & $72 \%$ & $82 \%$ & $87 \%$ \\
\hline$\%$ time above comfort zone & $10 \%$ & $3 \%$ & $4 \%$ & $8 \%$ \\
\hline \multicolumn{5}{|c|}{ Sleeping room south } \\
\hline Mean temp \pm stand.deviation $\left[{ }^{\circ} \mathrm{C}\right]$ & $24,3 \pm 1,4$ & $24,1 \pm 1,1$ & $24,8 \pm 1,6$ & $24,8 \pm 1,3$ \\
\hline$\%$ time in comfort zone & $70 \%$ & $77 \%$ & $63 \%$ & $78 \%$ \\
\hline$\%$ time above comfort zone & $15 \%$ & $2 \%$ & $22 \%$ & $16 \%$ \\
\hline
\end{tabular}

Table 4.Overheating indicator and risk for active cooling for all houses

\begin{tabular}{lcccc}
\hline & House 1 & House 2 & House 3 & House 4 \\
\hline Overheating indicator [Kh] & 13.494 & 11.548 & 6.118 & 8.945 \\
Risk for active cooling system [\%] & $58 \%$ & $37 \%$ & $0 \%$ & $10 \%$ \\
\hline
\end{tabular}

\subsection{Relative humidity, $\mathrm{CO}_{2}$ concentration and indoor air quality}

The RH was within the comfort zone of 30-70\% for most of the time. In winter in house 1 and 3 , the $\mathrm{RH}$ was below $30 \%$ during $1 \%$ of the time and in house 2 during $5 \%$ of the time, but only $0,5 \%$ of the time below $25 \%$. In summer only in house 3 , the $\mathrm{RH}$ was above $70 \%$ during $1 \%$ of the time. Since human beings are very insensitive for $\mathrm{RH}$ and problems with $\mathrm{RH}$ are more related to high $\mathrm{RH}$ levels (due to risk for moisture damage), these results are very satisfactory, there will be no further discussion on the RH.

Figure 2 shows for each house the percentage of time the different IAQ levels were reached in the living room during the months November 2009 till January 2010. 


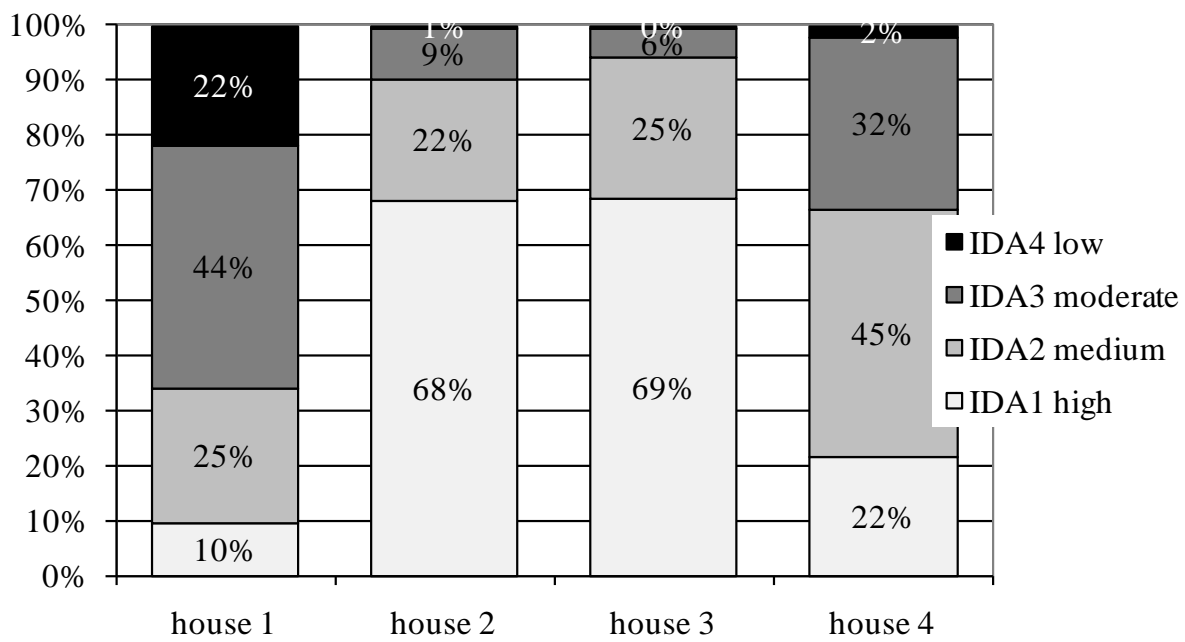

Fig. 2. Percentage of time IAQ levels are reached in each living room during Nov. 2009 till Jan. 2010.

\section{Discussion}

\subsection{Energy consumption}

As figure 1 shows, the monitored primary energy consumption is lower than the maximum allowable for all houses, except for the renovated house 3. However, the monitored consumption includes also the electricity for household and lighting, which is not included in the maximum allowable value. Furthermore, the calculated energy consumption assumes a mean indoor temperature of $18^{\circ} \mathrm{C}$, whereas the monitored rooms in house 1,3 and 4 have an overall mean indoor temperature higher than $18^{\circ} \mathrm{C}$, except for house 2 . This way, it can be concluded that all houses perform better than the current legal standard. The results also show that the houses with condensing boiler (house 2 and 4) perform best and better than calculated in theory. In house 1 the wood consumption is very high, with an energy consumption for heating, higher than the calculated energy consumption (bar 2 vs. bar 4 in figure 1), whereas in house 3 the electricity consumption is very high. For house 1 this might be explained by the higher indoor temperature in the living room, and for house 3 by the electrical backup heating of domestic hot water and the electrical heater in the bathroom. Remarkably, none of the houses has temperature setback during night or absence, probably due to the high inertia of the installed system (soapstone wood stoves and/or floor heating). The occupants with soapstone stove slightly complain about the fact that the massive heating system is not easily adaptable to changing temperatures, thus causing overheating in winter at some moments.

\subsection{Thermal comfort}

The measured temperature in winter in the living room remains in the comfort zone for all houses, except for house 3, where the temperature slightly decreases during cold days. However, for the occupants the indoor temperature is never too cold, only sometimes slightly too warm. For the sleeping rooms, only the occupants of house 2 complain about the cold temperature in the north oriented sleeping room, but they never choose to put on the radiators in this room. For the other sleeping rooms of all houses, there were no complaints, although the measurements showed lower mean temperatures. This is probably due to the fact that these rooms are only used for sleeping and not for studying.

For the summer, the calculations showed a risk for overheating in house 1 and 2, but hardly any risk for house 3 and 4 . However, in house 1 , despite temperatures $>26^{\circ} \mathrm{C}$ during $10-15 \%$ of the time in all rooms, the occupants only had small complaints of overheating in the living 
room and the south oriented sleeping room. In house 2, the monitoring did not show any overheating, although the occupants complained of overheating in the living room and the south oriented sleeping room and the overheating indicator indicates a $37 \%$ change that active cooling will be installed. The occupants of house 3 and 4 strongly complained of overheating in the south oriented sleeping room, which was confirmed by the measurements, but not predicted by the overheating indicator, that only assesses the overall thermal comfort.

\subsection{Indoor air quality}

Concerning IAQ, the monitoring showed a satisfactory IAQ in the living room of house 2 and 3 during more than $90 \%$ of the time. However, the occupants of house 3 were not totally satisfied with the IAQ and also had complaints about draft. The occupants of house 2 had no complaints on the IAQ. The IAQ was worst in house 1 and this was also confirmed by the occupants. In despite of the presence of a balanced ventilation system, they ventilate the sleeping rooms by opening windows and the living room by opening the door between sun porch and living room. They also confessed to adapt their behavior depending on the $\mathrm{CO}_{2}$ value on the monitoring equipment. In house 4, the moderate IAQ can be explained by the fact that the balanced ventilation system was not yet installed. The occupants only ventilated by opening windows in the north oriented sleeping room in the morning.

\section{Conclusions}

This research shows that although the four houses are performing better than the current legal standard, there still is quite some potential for improvement. Especially the choice and use of the heating system can be improved. The soapstone wood stove has been chosen for its environmental friendliness, but practice shows that control of the system is very difficult. A robust and simple system like the condensing boiler shows to be a more energy saving solution. Furthermore, it can be concluded that there is no adequate comfort theory to assess the thermal comfort in dwellings, as the existing theories are developed for office buildings. Finally, design of low energy houses should not only focus on low energy consumption during winter, but also on good summer comfort to avoid installation of cooling afterwards by less environmentally conscious occupants. To assess the summer performance of a dwelling, summer comfort should be evaluated in detail during design and on room or zone level, based on an appropriate comfort theory.

\section{References}

[1] VEA, Press release of the Minister of Energy and Housing, Flemish new houses much more energy saving than 4 years ago!, 5 March 2010, www.energiesparen.be/node/1869.

[2] Guerra Santin O. (2010) Actual energy consumption in dwellings (PhD Dissertation T.U.DELFT). Series Sustainable Urban Areas 33, 252 pages, Amsterdam (IOS Press).

[3] van den Ham E.R., Leyten J.L. et al. (2009) Robust climate design as a concept for comfortable, healthy and energy efficient indoor spaces. Proceedings of the $4^{\text {th }}$ International Building Physics Conference. Energy Efficiency and New Approaches. Bayazit, Manioglu, Oral \& Yilmaz (eds.) June 15-18 2009, Istanbul, Turkey.

[4] ISO 7730:1994 Moderate thermal environments - Determination of the PMV and PPD indices and specification of the conditions for thermal comfort.

[5] Van der Veken J., Saelens D. et al. (2004) Comparison of steady-state and dynamic building energy simulation programs. Proceedings of the International Buildings IX ASHREA Conference, Clearwater Beach, Florida. 